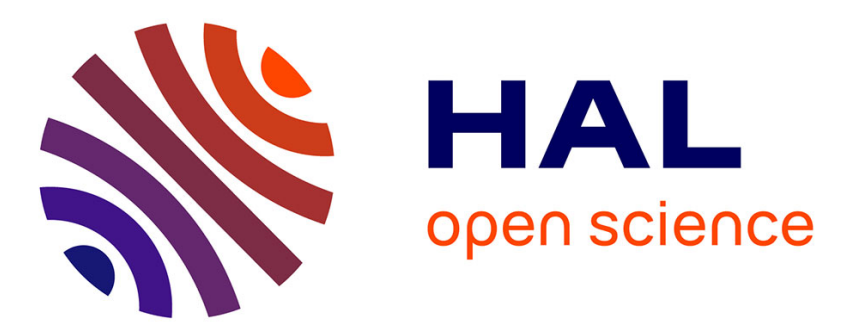

\title{
Occurrence and seasonal variations of algal toxins in water, phytoplankton and shellfish from North Stradbroke Island, Queensland, Australia
} Eri Takahashi, Qiming Yu, Geoff Eaglesham, Des W. Connell, James Mcbroom, Simon Costanzo, Glen R. Shaw

\section{To cite this version:}

Eri Takahashi, Qiming Yu, Geoff Eaglesham, Des W. Connell, James Mcbroom, et al.. Occurrence and seasonal variations of algal toxins in water, phytoplankton and shellfish from North Stradbroke Island, Queensland, Australia. Marine Environmental Research, 2007, 64 (4), pp.429. 10.1016/j.marenvres.2007.03.005 . hal-00562976

\section{HAL Id: hal-00562976 https://hal.science/hal-00562976}

Submitted on 4 Feb 2011

HAL is a multi-disciplinary open access archive for the deposit and dissemination of scientific research documents, whether they are published or not. The documents may come from teaching and research institutions in France or abroad, or from public or private research centers.
L'archive ouverte pluridisciplinaire HAL, est destinée au dépôt et à la diffusion de documents scientifiques de niveau recherche, publiés ou non, émanant des établissements d'enseignement et de recherche français ou étrangers, des laboratoires publics ou privés. 


\section{Accepted Manuscript}

Occurrence and seasonal variations of algal toxins in water, phytoplankton and shellfish from North Stradbroke Island, Queensland, Australia

Eri Takahashi, Qiming Yu, Geoff Eaglesham, Des W. Connell, James

McBroom, Simon Costanzo, Glen R. Shaw

PII:

S0141-1136(07)00046-3

DOI:

10.1016/j.marenvres.2007.03.005

Reference:

MERE 3113

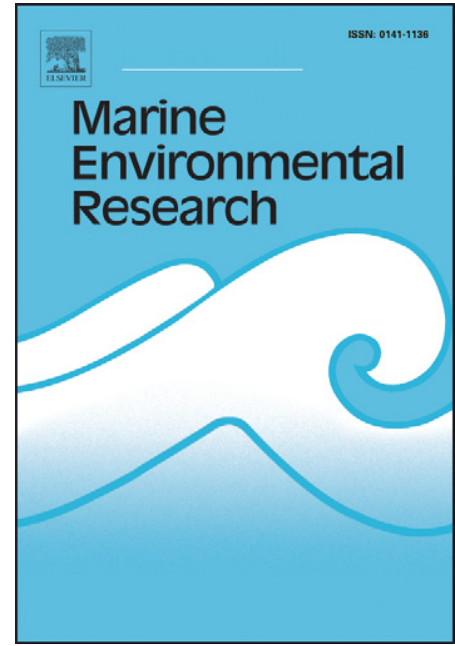

To appear in:

Marine Environmental Research

Received Date: $\quad 14$ November 2005

Revised Date: $\quad 2$ February 2007

Accepted Date: $\quad 11$ March 2007

Please cite this article as: Takahashi, E., Yu, Q., Eaglesham, G., Connell, D.W., McBroom, J., Costanzo, S., Shaw, G.R., Occurrence and seasonal variations of algal toxins in water, phytoplankton and shellfish from North Stradbroke Island, Queensland, Australia, Marine Environmental Research (2007), doi: 10.1016/j.marenvres.2007.03.005

This is a PDF file of an unedited manuscript that has been accepted for publication. As a service to our customers we are providing this early version of the manuscript. The manuscript will undergo copyediting, typesetting, and review of the resulting proof before it is published in its final form. Please note that during the production process errors may be discovered which could affect the content, and all legal disclaimers that apply to the journal pertain. 
Occurrence and seasonal variations of algal toxins in water, phytoplankton and shellfish from North Stradbroke Island, Queensland, Australia

Authors:

Eri Takahashi ${ }^{1,2 *}$, Qiming $\mathrm{Yu}^{3}$, Geoff Eaglesham ${ }^{4}$, Des W. Connell ${ }^{2}$, James McBroom ${ }^{2}$, Simon Costanzo ${ }^{1}$, Glen R. Shaw ${ }^{5}$

1. National Research Centre for Environmental Toxicology (EnTox), 39 Kessels Road, Coopers Plains, QLD 4108, Australia

2. Australian School of Environmental Science, Griffith University, Nathan Campus, Brisbane, QLD 4111, Australia

3. School of Environmental Engineering, Griffith University, Nathan Campus, Brisbane, QLD 4111, Australia

4. Queensland Health Pathology and Scientific Services, 39 Kessels Rd, Coopers Plains QLD 4108, Australia

5. School of Public Health, Griffith University, Academic 1 3.21, University Dr, Meadowbrook, QLD 4131, Australia

*Corresponding author: Telephone: +61 73274 9147; Fax: +61 73274 3009; e-mail: e.takahashi@uq.edu.au; postal address: EnTox, 39 Kessels Rd., Coopers Plains, QLD 4108, Australia. 


\section{Abstract}

A number of marine microalgae are known to produce toxins that can accumulate in shellfish and when eaten, lead to toxic and potentially fatal reactions in humans. This paper reports on the occurrence and seasonal variations of algal toxins in the waters, phytoplankton and shellfish of Southeast Queensland, Australia. These algal toxins include okadaic acid (OA), domoic acid (DA), gymnodimine (GD), pectenotoxin-2 (PTX-2) and pectenotoxin-2-seco acid (PTX-2-SA), which were detected in the sampled shellfish and phytoplankton, via HPLC-MS/MS. Dissolved OA, PTX-2 and GD were also detected in the samples collected from the water column. This was the first occasion that DA and GD have been reported in shellfish, phytoplankton and the water column in Queensland waters. Phytoplankton tows contained both the toxic Dinophysis and Pseudo-nitzschia algae species, and are suspected of being the most likely producers of the OA, PTX-2s and DA found in shellfish of this area. The number of cells, however, did not correlate with the amount of toxins present in either shellfish or phytoplankton. This indicates that toxin production by algae varies with time and the species present and that number of cells alone cannot be used as an indicator for the presence of toxins. The presence of OA and PTX-2s were more frequently seen in the summer, while DA and GD were detected throughout the year and without any obvious seasonal patterns.

Keywords: okadaic acid, domoic acid, gymnodimine, shellfish toxins, Dinophysis, Pseudo-nitzschia

\section{Introduction}

Toxic shellfish poisonings occur when algal toxins are transferred through the food chain to higher trophic levels, including humans. Diarrhetic shellfish poisoning (DSP), named after the human symptom of gastroenteritis, is one such example (Yasumoto, Seino, Murakami and Murata, 1987, Carmody, 1996) (Fernandez, Reguera, GonzalezGil and Miguez, 2006). Within DSP, there are lipophilic group of toxins: okadaic acid (OA), dinophysis toxins (DTXs) and pectenotoxins (PTXs), which are produced by dinoflagellates (Yasumoto et al., 1987, Yasumoto and Murata, 1990, Draisci, Lucentini, Giannetti, Boria and Poletti, 1996, James, 1999, Fernandez et al., 2006). These toxins are harmful to humans and pose a serious threat to aquaculture industries (Fernandez, 2000). The OA group is responsible for causing diarrhoea, inhibiting 
protein-phosphatase enzymes and has the potential to be a tumour promoter (Fujiki, 1990, Creppy, Traore, Baudrimont, Cascante and Carratu, 2002). Although PTXs do not cause such diarrhoea related illnesses, they were formally placed into this group since they are commonly found with the OA (Fernandez, 2000, Creppy et al., 2002, Miles, Wilkins, Munday, Dines, Hawkes, Briggs et al., 2004). To date, no records of OA have been recorded in the waters around Southeast Queensland.

Domoic acid (DA) is a toxin produced by diatoms from the genus Pseudo-nitzschia, and is known to cause amnesic shellfish poisoning (ASP) (Van Dolah, 2000, Jeffery, Barlow, Moizer, Paul and Boyle, 2004). Toxic reactions to DA in humans include abdominal cramps, vomiting, diarrhoea, disorientation, short term memory loss and even death (Perl, Bedard and Kosatsky T, 1990). It has been documented to affect, not only humans, but marine organisms such as marine mammals and sea birds (Lefebvre, Powell, Busman, Doucette, Moeller, Silver et al., 1999, Gulland, Haulena, Fauquier, Langlois, Lander, Zabka et al., 2002, Shumway, 2003). Although DA has been detected in Australia, there has not been any reported incidences of ASP in Australia (Lapworth, Hallegraeff and Ajani, 2000).

Gymnodimine (GD) was first detected in New Zealand in 1994 (Seki, Satake, Mackenzie, Kaspar and Yasumoto, 1995, Stirling, 2001). This toxin is a compound produced by dinoflagellates from the genus Karenia, with Karenia selliforme being associated with the toxin in New Zealand (Seki et al., 1995, Mackenzie and Beuzenberg, 2003). Although this compound has low toxicity when introduced orally, it is a fast acting toxin when it is injected intraperitoneally (ip) into mice (Stirling, 2001). Due to its high potency when injected into mice, GD can cause Type I errors (false positive) during mouse bioassays designed to test for paralytic and neurotoxic shellfish poisoning (Seki et al., 1995).

This study assesses the occurrence and seasonal variations of marine algal toxins in shellfish and phytoplankton collected from waters around North Stradbroke Island, located in Moreton Bay, southeastern Queensland. The waters around the island yield a variety of shellfish, some of which are consumed by the locals and sold to the public by oyster lease owners. Although there have been no reported incidences of algal toxin poisoning around the study sites, algal blooms have been observed around the 


\section{ACCEPTED MANUSCRIPT}

island (Osborne, Webb and Shaw, 2001). The work presented here provides information in qualifying and quantifying the potential hazard posed by endemic forms of marine algal toxin to the consumers of the shellfish caught in these waters. In this study, OA, DA, PTX-2s and GD were detected from the sampling sites, and their exposure to the consumers was estimated.

\section{Material and Methods}

\subsection{Sample collection}

Sampling for this study was conducted monthly for 24 consecutive months from July 2003 to June 2005, in Moreton Bay, on the east-coast of Australia $\left(27^{\circ} 15 \mathrm{~S}, 153^{\circ}\right.$ 15E) (Fig. 1). Moreton Bay is a sub-tropical, shallow coastal embayment $\left(1.5 \times 10^{3} \mathrm{~km}^{2}\right)$ bordered by sand barrier islands to the east (Moreton Island and North and South Stradbroke Islands). A total of six sampling sites were selected for shellfish collection and phytoplankton tows, three within Moreton Bay and three along the exposed beach of North Stradbroke Island (Fig 1). Site 1 was a bank in between the Myora lights and North Stradbroke Island; Site 2 was an oyster lease located within the bay at Palmer Passage; and Site 3 was Amity Jetty on the northern tip of North Stradbroke Island. The three sites on the open ocean beach side included Site 4 on Flinders Beach, facing north; and two sites along Main Beach facing the Pacific Ocean (sites $5 \&$ 6). Oysters (Saccostrea glomerata) were collected from Sites 1, 2 \& 3; mussels (Modiolus proclivis) were collected at Sites $1 \& 2$; and pipis (Donax deltoides) were collected from Sites 4, $5 \& 6$ along the ocean beaches.

At each of the six sites, a plankton net (diameter $30 \mathrm{~cm}$, mesh size $30 \mu \mathrm{m}$ ) was towed behind the boat for $50 \mathrm{~m}$ at a depth of up to $1 \mathrm{~m}$. A $15 \mathrm{~mL}$ aliquot of the captured material was preserved in Lugol's iodine for microscopic observation. The remainder of the towed sample material was kept in a plastic container cold on ice and brought back to the laboratory. A flow meter was attached to the net to enable quantification of the water flow through the net, and was later used to calculate the amount of cells per volume of water.

Solid phase adsorption toxin tracking (SPATT) bags (Cawthron Institute), containing porous synthetic resin designed to accumulate dissolved lipophilic toxins, were 


\section{ACCEPTED MANUSCRIPT}

deployed to assess dissolved toxins in the water column (Mackenzie and Beuzenberg, 2003). SPATT bags were deployed at Sites 1 and an additional site within the bay, Rous Channel (Site 7).

\subsection{Microscopic observation of phytoplankton}

Plankton net tow samples were examined by phase contrast microscopes (Nikon Labphot; Graticules, UK) at 400x magnification. A 15-mL aliquot of phytoplankton tow sample material was inverted 20 times to thoroughly mix the samples. One $\mathrm{mL}$ of the 15-mL aliquot was placed on a Sedgewick Slide. The number of OA, PTX-2 and DA producing species from the genera Dinophysis and Pseudo-nitzschia were identified and recorded (per one $\mathrm{mL}$ ) for each of the samples. This was then multiplied by 1000 to obtain the estimated cell number per L. The mean and standard deviation were calculated per monthly sampling.

For speciation of the diatom of Pseudo-nitzschia, transmission electron microscope (TEM) (model 100SX, JEOL) was used for microscopic investigation (Fehling, Green, Davidson, Bolch and Bates, 2004). Samples were acid cleaned following published protocols (Villac and Fryxell, 1998, Lundholm, Daugbjerg and Moestrup, 2002, Fehling et al., 2004). Fifteen mL of the concentrate from each of the tows was left overnight in a solution of $1 \mathrm{~mL} 10 \% \mathrm{HCL}, 2 \mathrm{~mL} 30 \% \mathrm{H}_{2} \mathrm{SO}_{4}, 10 \mathrm{~mL}$ saturated $\mathrm{KMnO}_{4}$. Saturated oxalic acid was added to remove the stain from $\mathrm{KMnO}_{4}$. Samples were centrifuged (1500 g) and rinsed three times with DI water. Acid cleaned samples were then mounted on 200 micron mesh copper grid (ProSciTech, Thuringowa, Australia) with polyethylenimine (PEI). Specific taxonomic characters described by Skov et al (Skov, Lundholm, Moestrup and Larsen, 1999) were used for species identification.

For the samples in which GD were detected, a 15-mL aliquot of the phytoplankton samples were sent to Cawthron Institute for DNA probe analysis for the identification of Karenia selliformis (Rhodes, Mackenzie and Kaspar, 2001).

\section{$\underline{2.3 \text { Toxin extraction }}$}

Toxins were extracted from macerated shellfish using the methods described in previous studies (Lee, Toshihiko, Kenma and Yasumoto, 1987, Marr, McDowell and 


\section{ACCEPTED MANUSCRIPT}

Quilliam, 1994). Shellfish flesh (4 g) were homogenised with $16 \mathrm{ml} 80 \%$ methanol. After separation by centrifugation (2700 $\mathrm{g}$ for ten minutes) the methanol extract was washed with an equal volume of hexane, and filtered $(0.45 \mu \mathrm{m})$ for analysis. Esters of okadaic acid (DTX-3) were hydrolysed to okadaic acid, DTX1 and/or DTX2 by using base hydrolysis (Mountfort, Suzuki and Truman, 2001). A $200 \mu \mathrm{L}$ aliquot of methanol extract was taken and hydrolysed in $2 \mathrm{M} \mathrm{NaOH}$ at $75^{\circ} \mathrm{C}$ for 45 minutes then neutralised using $\mathrm{HCl}$. These samples were then filtered $(0.45 \mu \mathrm{m})$ and analysed using HPLC-MS/MS.

For the extraction of toxins from plankton net tows, the protocol by Pan et al. (Pan, Cembella and Quilliam, 1999) was incorporated. Samples were centrifuged at $2700 \mathrm{~g}$ for ten minutes. The pellets were boiled at $100^{\circ} \mathrm{C}$ for five minutes in order to both release the toxins from phytoplankton cells and to stop the enzymes from degrading the toxins. Phytoplankton toxins were extracted in $80 \%$ methanol, the eluate was evaporated dry under $\mathrm{N}_{2}$, re-dissolved in $200 \mu \mathrm{L} 80 \%$ methanol, filtered $(0.45 \mu \mathrm{m})$ and analysed via HPLC-MS/MS.

Dissolved toxins in the water column were extracted from the SPATT bags following the method previously been developed (Mackenzie, Beuzenberg, Holland, McNabb and Selwood, 2004). The bags were rinsed twice in fresh water for five minutes to remove any surface materials attached on the mesh. The resins from the SPATT bags were emptied into $100 \%$ methanol for two hours. The solvent was then filtered through glass wool and an anhydrous $\mathrm{NaSO}_{4}$ column to remove any water. The sample was rotary vacuum-evaporated, re-suspended in $5 \mathrm{~mL} 80 \%$ methanol and dried under a $\mathrm{N}_{2}$ blower. The dried material was then re-suspended into $2 \mathrm{~mL} 80 \%$ methanol, filtered $(0.45 \mu \mathrm{m})$ and analysed.

All extracts from shellfish, phytoplankton tows and SPATT bags were analysed by using an AB/Sciex API 300 mass spectrometer (Applied Biosystems, Concord, Canada) coupled to a Perkin Elmer 200 series HPLC system (Perkin Elmer, Norwalk, USA) by a high flow Electrospray interface (Turbo-Ionspray). Analytes were separated on an Alltima C18 column (150 x 4.6 mm, Alltech Associates, Deerfield, IL.) with a mobile phase of acetonitrile, $2 \mathrm{mM}$ ammonium formate and $0.1 \%$ formic 
acid gradient at a flow rate of $0.8 \mathrm{~mL} \mathrm{~min}^{-1}$. The mass spectrometer was operated in the positive ion mode for PTX, GD and DA and negative ion mode for OA, DTX1, 2 and 3 .

\subsection{Statistics}

Data collected from the beach and the bay were pooled separately. Two analyses were conducted; one on the toxins extracted from the phytoplankton and the other from the shellfish. Two models were run for each of the analysis: logistic regression and linear mixed models to assess the relation between toxin production and seasonal pattern, temperature variation and presence of specific algae. The logistic regression model allowed the probability of presence of the toxins to be calculated. The linear mixed model was used to incorporate time series correlation as all samples were collected from specific sites, every month, for two consecutive years. These models also partitioned variation, created by the hierarchical nature of the experimental design of having three sites within the two separate locations, beach and bay.

For the first set of logistic regression models on phytoplankton data, the effects of temperature, seasons, sampling sites within locations and phytoplankton genus on presence or absence of toxins were investigated. This was then repeated for each of the toxins separately. Linear mixed models were conducted on combined toxin data, and then on each of the toxins individually.

\section{$\underline{2.5 \text { Calculation of dissolved toxins in water column }}$}

For quantification of SPATT bag data, the n-octanol-water partition coefficient $\left(\mathrm{K}_{\mathrm{ow}}\right)$ was estimated by graphing log HPLC-MS/MS retention times of similar chemicals with known $\log \mathrm{K}_{\mathrm{ow}}$. The SPATT bags were spiked with a known amount of OA in $500 \mathrm{~mL}$ beaker for duration of one week. Toxin concentration in the water was extrapolated using the information on toxins extracted from the SPATT bags and the calculated spatt-water partition coefficient $\left(\mathrm{K}_{\mathrm{sw}}\right)$ (Formula 1). To obtain $\mathrm{K}_{\mathrm{sw}}$ for GD and PTX-2, the relation between $\mathrm{K}_{\mathrm{ow}}$ and $\mathrm{K}_{\mathrm{sw}}$ for OA was used (Formula 2).

Formula 1: $\quad \mathrm{Ksw}=\frac{\text { Toxin in SPATT }}{\text { Toxin in water }}$ 
Formula 2: $\quad$ Ksw toxin $=\left(\frac{\text { Kow toxin }}{\text { Kow OA }}\right) \times$ Ksw OA

\section{$\underline{2.6 \text { Exposure assessment }}$}

Estimates of potential exposure to algal toxins were based on average daily shellfish intake of $250 \mathrm{~g} \mathrm{day}^{-1}$ (Toyofuku, 2006) and the calculated abundance of shellfish toxin. Estimated daily exposure (DE) levels for humans were calculated by multiplying the toxin concentration per weight of shellfish tissue by the known daily consumption of shellfish (Formula 3). For the toxins in shellfish, both mean concentrations of toxins and maximum concentrations of the toxins from monthly field collection around North Stradbroke Island were used. Additionally, information on abundance of dinoflagellates and levels of okadaic acid were obtained from pipi harvesters in South Australia and was also incorporated into the exposure assessment.

These data were used to calculate the estimated toxin level or the daily intake (DI) by dividing the DE by the body weight (BW; Formula 4). The assumed mean body weight for humans was $70 \mathrm{~kg}$.

Formula 3: $\quad \mathrm{DE}=$ Toxin in food $\times$ daily consumption

Formula 4: $\quad \mathrm{DI}=\frac{\mathrm{DE}}{\text { mean } \mathrm{BW}}$

\section{Results}

\section{$\underline{3.1 \text { Species identification }}$}

The occurrence of Dinophysis and Pseudo-nitzschia are plotted in Fig. 2a and b.

These plots indicate that Dinophysis genus was present during the warmer months and was more prominent in the open beaches than in the bay. D. caudata was more abundant in November and January 2004, with the highest concentration of 15 cells L-

${ }^{1}$ recorded from the open beaches. D. acuminata was also present between November 2004 and January 2005, and only seen on the open beaches (data not shown).

Pseudo-nitzschia, was observed throughout the course of the investigation (Fig. 2b), with the highest concentration of 70 cells $\mathrm{L}^{-1}$ being observed in the bay in February 
2005 (raw data not shown). The TEM analysis (Table 1) identified several species of Pseudo-nitzschia (P. pungens, P. pseudodelicatissima, P. lineola and P. fraudulenta) as potential producers of DA during February 2005 when DA was present in the phytoplankton samples.

From the $15 \mathrm{~mL}$ aliquot samples sent to Cawthron Institute, Karenia selliformis was detected using the DNA probe analysis. This confirms that $K$. selliformis are the most likely producer of GD in sampled area.

\section{$\underline{3.2 \text { Toxins from phytoplankton }}$}

All the toxins detected from phytoplankton and shellfish samples are summarised in Table 2. Total dissolved algal toxin concentrations were calculated using a logistic regression model. The results indicated that the samples collected during spring and summer were not significantly different from one another while both were significantly different to samples collected in autumn $(\mathrm{P}<0.05)$. There was no observed statistical difference between the sampling sites with regards to the probability of observing toxins.

Data analysed via a linear mixed model showed that combined toxin concentrations were positively related to the rise in temperature $(\mathrm{p}<0.05)$. Greater statistical variation in presence of toxins was observed between beach and the bay sampling sites than was observed within the sampling sites.

Overall, PTX-2 was most abundant toxin detected from phytoplankton samples collected around North Stradbroke Island, with maximum of $0.26 \mu \mathrm{g} \mathrm{L}^{-1}$ (Fig. 3a). D. caudata was significantly correlated to the presence of PTX-2 and PTX-2SA $(p<0.05)$. Linear mixed model analysis revealed that there was significantly more PTX-2 found during summer and spring than in autumn (p<0.05) (Fig. 3b).

Analyses with seasons as an explanatory variable in the logistic regression model showed that there was a strong correlation between Pseudo-nitzschia and the presence of DA ( $\mathrm{p}<0.05)$, however, it was only 1.06 times more likely for DA to be present than not when Pseudo-nitzschia were detected. For example, in some samples, no DA was detected even though more than 70 cells L $\mathrm{L}^{-1}$ of Pseudo-nitzschia were present (Fig. 3c). The high abundance in February 2005 did, however, correlate with the high levels 
of DA in the phytoplankton tows. Overall, the occurrence of DA in the beach and the bay were low (sample size of four and five per site), and on average the concentrations were observed to be higher in samples collected from the beach.

Gymnodimine was detected for the first time in Australia with a maximum concentration of $0.006 \mu \mathrm{g} \mathrm{L}^{-1}$ collected from plankton net sampling (Table 2; Fig. 3d). This toxin was present throughout the year with higher concentrations of GD observed during summer than in winter $(\mathrm{p}<0.05)$.

\section{$\underline{3.3 \text { Toxins in shellfish }}$}

Using the logistic regression model, the presence of PTX-2SA was significantly higher in summer and spring compared to autumn $(\mathrm{p}<0.05)$, and was correlated with the rise in temperature $(\mathrm{p}<0.05)$ (Fig. 3b). Linear mix model for PTX-2SA showed that there was significant variation between two locations whilst not much variation between the sites within the beach. The frequency of PTX-2, detected in shellfish, was too low for any statistical analysis.

Domoic acid was found in all three types of shellfish, with maximum of $256 \mathrm{~g} \mathrm{~kg}^{-1}$, in pipis in December 2004 (Table 2). While DA was related to decrease in temperature $(\mathrm{p}<0.05)$, using the logistic regression model, there were no seasonal patterns in the presence of the toxins (Fig. 3c). Linear mix model for DA showed opposite of PTX2SA, as there was little variation between the beach and the bay, whilst high variation between the three sites within each of the two locations.

Presence of GD was also significantly higher in summer and spring, as well as in winter, when compared to autumn $(\mathrm{p}<0.05)$ (Fig. 3d). Highest amounts of GD were found in pipis with the maximum of $220 \mu \mathrm{g} \mathrm{kg}^{-1}$ and lowest in oysters with maximum of $43 \mu \mathrm{g} \mathrm{kg}^{-1}(\mathrm{p}<0.05)$. The linear mixed model for GD showed high variation between both locations and sites. It was also positively correlated to the temperature of the water $(\mathrm{p}<0.05)$.

Detectable amounts of OA (maximum $44.5 \mu \mathrm{g} \mathrm{kg}^{-1}$ ) were found in pipis collected from the open ocean side of the island between November 2004 and February 2005 
(Fig. 3e), however, frequency of occurrence of OA was too low for a valid statistical analysis to be performed. Despite the presence of Dinophysis, no DTX's were found in shellfish or plankton towed samples from the study sites.

\subsection{Dissolved toxins in water column}

Lipophilic toxins, PTX-2, OA and GD were extracted from SPATT bags deployed within the bay. PTX-2 was the most abundant toxin, with a maximum amount in November 2004 (Fig. 4). The maximum OA was in February 2005 and maximum GD was in August 2004. From plotting the log retention times obtained from HPLC column, $\log$ of $\mathrm{K}_{\mathrm{ow}}$ for OA (3.4), PTX-2 (3.7) and GD (2.2) were calculated. From the laboratory experiment with spiked SPATT bags, SPATT-water partition coefficient $\left(\mathrm{K}_{\mathrm{sw}}\right)$ for OA was determined and information $\mathrm{K}_{\mathrm{sw}}$ for the other toxins were estimated. Using these $\mathrm{K}_{\mathrm{sw}}$, the mean and maximum concentration in the water for PTx-2, GD and OA were calculated (Table 3).

\section{$\underline{3.5 \text { Exposure assessment }}$}

The daily exposure (DE) of OA, DA, GD and PTX-2s to humans was calculated for each of the toxins (Table 4). Both the mean and maximum DE for each of the toxins from both Queensland and South Australia was calculated. The only data available from South Australia were on OA and PTX-2, whilst OA, DA, GD and PTX2 were observed in Queensland shellfish. Toxin levels were higher in South Australia than Queensland samples. Toxins recorded from South Australia were up to 100 folds higher than those of Queensland.

\section{Discussion}

The Dinophysis detected around the North Stradbroke Island were most abundant during the warmer months and thereby, displayed similar trends to other members of this genus found in other geographical locations (Hallegraeff, 2002). In this study, D. acuminata was only detected in the second year of sampling, and they were only found in late spring and summer. Similar trends were seen in Portugal, where, the presence of D. acuminata are assumed to be related to organic nutrients (Vale and Sampayo, 2003). Studies conducted in the Adriatic Sea describe a difference in presence between D. caudata and D. acuminata (France and Mozetic, 2006), however, due to the limited occurrence of $D$. acuminata in this study, no seasonal distinction 
between the two species were made. The occurrence of OA did, however, coincide with the presence of $D$. acuminata, making this species the most likely producer of OA in this area. These results are supported by those of other studies associating $D$. acuminata with OA (Hallegraeff, 1992, Hallegraeff, 2002, Madigan, Lee, Padula, McNabb and Pointon, 2006).

The maximum concentration of OA $\left(44.5 \mu \mathrm{g} \mathrm{kg}^{-1}\right)$ found in pipis, is lower than the recommended safety limit of $160 \mu \mathrm{g} \mathrm{kg}^{-1}$ (FAO, 2004), hence at present, the risk of acute effects from OA exposure to humans from consuming pipis from the waters around North Stradbroke Island during the sampling period is low. OA was not detected in mussels or oysters during the sampling period, indicating that OAproducing Dinophysis are most likely found in the open ocean side of the island and not within the bay. It is possible that the East Australian Current (EAC) running along the eastern coast of the island may be responsible for this effect. The current runs all year around, but predominantly in summer, bringing warmer tropical water southwards and this additional warmth may assist in an increased rate and occurrence of algal growth. Toxin production by Dinophysis has been reported to be related to water temperature, salinity, rainfall and nutrient levels (France and Mozetic, 2006, Vale, 2006). The current study only compared the temperature to the presence of toxins. Future studies on the role of ecological influences on the abundance of toxic algae will further our understanding on algal toxin production.

Both PTX-2s were observed in the warmer months, peaking in November 2004. This correlated to the presence of $D$. caudata, making this species the most likely producer of these toxins. This species has recently been reported to produce PTX-2 in northwest Spain (Fernandez et al., 2006). The less toxic form (PTX-2SA) is a metabolite of PTX-2 and not known to be produced by phytoplankton directly (Miles et al., 2004, Wilkins, Rehmann, Torgersen, Rundberget, Keogh, Petersen et al., 2006). The presence of PTX-2SA in the phytoplankton samples analysed in this study may have resulted from the breakdown of PTX-2 after either being released into the water column or after the cells have died during the sampling or transportation processes, hence the observed significant relationship may not be relevant in this case.

In shellfish, PTX-2s were more abundant in the pipis (ocean side) than in oysters and 
mussels which were found in the bay. In this study, PTX-2SA was only detected in the pipis. These results confirm that pipis are capable of converting PTX-2 into PTX2-SA, however the mechanism by which this degradation took place was not investigated. The blue mussels (Mytilus edulis) have been reported to convert PTX-2 to PTX-2SA in New Zealand and Ireland (MacKenzie, Holland, McNabb, Beuzenberg, Selwood and Suzuki, 2002, Wilkins et al., 2006). If PTX-2 was more abundant around North Stradbroke Island, PTX-2SA may have been present in the mussels and oysters also. Another explanation for there being lower observed incidence of PTX-2SA in mussels and oysters than in pipis may be that they are capable of rapidly eliminating the seco acid form.

Pseudo-nitzschia populations detected in this study were made of a numerous species among which, $P$. pseudodelicatissima, $P$. fraudulenta and $P$. pungens have been known to produce DA in other parts of the world (Lapworth et al., 2000, Hallegraeff, 2002). Further investigations utilising an RNA probe to screen toxic species may help identify the source of DA in this area (Miller, 1996, Scholin, 1997, Rhodes et al., 2001, Lundholm et al., 2002). In this study, the presence of Pseudo-nitzschia did not correlate with the seasons, but was found to be negatively related to the decreasing temperature. This observation is reflected in other studies where they are reported to bloom in winter, when other species are at the lowest (Mos, 2001).

Although the presence of DA and abundance of Pseudo-nitzschia was significantly correlated, there was no correlation between the presence of DA in phytoplankton and shellfish. Considering the plankton and shellfish samples were collected on the same day, there may not have been enough exposure time for the shellfish to accumulate the toxins in their organs, causing a time lag between potential detection in the two samples. This explains why the presence of domoic acid and the abundance of Pseudo-nitzschia may not correlate. Pseudo-nitzschia is known to produce toxins during the stationary phase of their growths, following a bloom (Bates, Freitas, Milley, Pocklington, Quillam, Smith et al., 1991). Since no algal blooms of this taxa were observed or reported during the study period, the population may never have reached this stationary phase to produce high levels of toxins. Another possible explanation for the lack of correlation between the presence of the Pseudo-nitzschia and DA could be because all the Pseudo-nitzschia species were pooled into a composite sample, 
however not all species are known to produce the toxins. Therefore, the samples which displayed an absence of DA may have been composed predominantly of the non-toxic Pseudo-nitzschia species. Furthermore, the low levels of DA and low number of cells encountered in the study may have been insufficient to form a concrete conclusion. For the duration of this study, DA posed no threat of acute health effects in humans as the maximum level detected was below the FAO guideline value of $20 \mathrm{mg} \mathrm{kg}^{-1}$ (FAO, 2004).

Gymnodimine has been reported for the first time in Australia from this study. Karenia selliformis is a known GD producer in New Zealand (Mackenzie and Beuzenberg, 2003, Miles, Wilkins, Stirling and MacKenzie, 2003), and this species was also present in Moreton Bay when GD was detected in the phytoplankton samples. Presence of $K$. selliformis was not monitored during the monthly sampling, however, the occurrence of GD correlated with the presence of $D$. caudata. This implies that $K$. selliformis are most probably found when other species of phytoplankton are present, as they were also more abundant in summer than in winter. The levels detected in shellfish were relatively low compared to the lethal level of $700 \mu \mathrm{g} \mathrm{kg}^{-1}$ when injected (ip) into mice (Stirling, 2001). Since gymnodimine has very low toxicity when dosed orally, these levels found around the island most probably would not cause risks to the consumers. However, since GD is known to have a slow depuration rate in oysters (Stirling, 2001), there is a potential for the toxin to remain in the ecosystem for a prolonged time.

Dissolved algal toxins were detected using the SPATT bags, indicating that algal toxins can be released by the dinoflagellates into the water column. It is interesting to note that OA was only detected in shellfish and phytoplankton tows collected from the oceanic (beach side) waters and not from the waters of the enclosed bay, while it was present in extracts from the SPATT bags deployed in the bay. This may be due to the fact that there are other dinoflagellates, from the genus Prorocentrum, that are known to produce OA (Murakami, Oshima and Yasumoto, 1982, Marr and Jackson, 1992, Koike, Sato, Yamaji, Nagahama, Kotaki, Ogata et al., 1998, Ten Hage, Delaunay and Pichon, 2000), and are present in Moreton Bay (Takahashi et al. submitted). Since Prorocentrum are benthic, they would not have been caught in the plankton net, towed just below the surface of the water. The chance of epiphytes contaminating the SPATT 


\section{ACCEPTED MANUSCRIPT}

extraction was considered to be minimal because the bags were rinsed with water prior to extraction, and only the resin within the bags were used for toxin extraction. This work compliments the detection of dissolved PTXs, OA, DTX-1 and YTX in SPATT bags from waters around Nelson, New Zealand (Mackenzie et al., 2004), which showed the availability of dissolved toxins in the water column. The sorption coefficient between SPATT bags and the concentration of toxins in water was estimated using laboratory experiment. However this calculated coefficient assumes the SPATT bags reached equilibrium within the 7 days of deployment. Further work is required to establish the duration for SPATT bags to reach equilibrium with algal toxins in the environment.

Data on DSP's obtained from South Australia were collected only when blooms of Dinophysis were observed (SASQAP, 2004), whilst those from Queensland were collected all year round for two years. Since there were no algal blooms observed during the two years of monthly collection in Queensland, it is understandable that both mean and maximum toxin levels in Queensland are up to 100 fold lower than that of South Australia. Data from South Australia, however, gives an insight into how much toxin could be present if a bloom. With the global incidence of harmful algae on the increase (Hallegraeff, 1993), possibly due to global warming and increased nutrient discharges into the estuaries and oceans (Mos, 2001), the possibility of a sudden algal bloom in this area remains likely. The nutrient levels within Moreton Bay have increased over the last 30 years (CSIRO, 2002). There have not been any recorded blooms of DSP's or ASP's around North Stradbroke Island, however the toxic cyanobacteria Lyngbya majuscula, has been known to bloom in this area (Osborne et al., 2001).

Data collected in this study have identified toxic algal species and their toxins in water and bivalves surrounding North Stradbroke Island. Levels of toxins and toxin producing algae were low and indicate that consumption of bivalves in the region is currently safe. Though with urban pressures on the bay increasing and numerous commercial oyster leases still in operation, we recommend algal toxins and toxinproducing algae be monitored to ensure the risk of bivalve consumption is managed. 


\section{Acknowledgement}

National Research Centre for Environmental Studies is funded by State of Queensland

- Queensland Health, Griffith University, The University of Queensland and

Queensland University of Technology. We thank the staff at Centre for Microscopy \&

Microanalysis at UQ and Dr Gustaaf Hallegraeff for the TEM analysis. The DNA

probe analysis for Karenia selliformis were conducted by Cawthron Institute. We also

thank Lincoln MacKenzie at Cawthron Institute for kindly providing the SPATT bags.

\section{References}

Bates S. S., Freitas D., Milley J. E., Pocklington R., Quillam M. A., Smith J. C. and Worms J. (1991). Controls of domoic acid production by the diatom Nitzschia pungens f. multiseries in culture: Nutrients and irradiance. Can J Fish Aquat Sci, 48, 1136-1144.

Carmody J. K. (1996). Dinophysistoxin-2: The predominant diarrhoetic shellfish toxin in Ireland. Toxicon, 3334, 351-359.

Creppy E. E., Traore A., Baudrimont I., Cascante M. and Carratu M.-R. (2002). Recent advances in the study of epigenetic effects induced by the phycotoxin okadaic acid. Toxicology, 181-182, 433-439.

CSIRO (2002) Moreton Bay Study: Keeping trouble at bay Ecos, (pp 15-17).

Draisci R., Lucentini L., Giannetti L., Boria P. and Poletti R. (1996). First report of pectenotoxin-2 (PTX-2) in algae (Dinophysis fortii) related to seafood poisoning in Europe. Toxicon, 34, 923-935.

FAO (2004) Marine Biotoxins FAO Food and Nutrition Paper 80, Rome, (pp Food and Agriculture Organization of the United Nations, Rome, 2004).

Fehling J., Green D. H., Davidson K., Bolch C. J. and Bates A. (2004). Domoic acid production by Pseudo-nitzschia seriata (Bacillariophyceae) in Scottish waters. Journal of Phycology, 40, 622-630.

Fernandez L., M., Reguera B., Gonzalez-Gil S. and Miguez A. (2006). Pectenotoxin-2 in single-cell isolates of Dinophysis caudata and Dinophysis acuta from the Galician Rias (NW Spain). Toxicon, 48, 477-490.

Fernandez M. L. (2000). Regulations for marine microalgal toxins: Towards harmonization of methods and limits. South African Journal of Marine Science, 22, 339-346.

France J. and Mozetic P. (2006). Ecological characterization of toxic phytoplankton species (Dinophysis spp., Dinophyceae) in Slovenian mariculture areas (Gulf of Trieste, Adriatic Sea) and the implications for monitoring. Marine Pollution Bulletin, 52, 1504-1516.

Fujiki H. (1990). Okadaic acid class of tumor promoters for mouse skin and rat glandular stomach tumor promotion and mechanims of action. 15th International Cancer Congress, Hamburg, Germany, August, 116

Gulland F. M., Haulena M., Fauquier D., Langlois G., Lander M. E., Zabka T. and Duerr R. (2002). Domoic acid toxicity in Californian sea lions (Zalophus californianus): clinical signs, treatment and survival. Vet Rec, 150, 475-480.

Hallegraeff G. (1993). A review of harmful algal blooms. Phycologia, 32, 79-99. 
Hallegraeff G. M. (1992). Harmful algal blooms in the Australian region. Marine Pollution Bulletin, 25, 186-190.

Hallegraeff G. M. (2002). Aquaculturists' Guide to Harmful Australian Microalgae. University of Tasmania, Hobart.

James K. J., Bishop, A. G., Healy, B. M., Roden, C., Sherlock, I. R., Twohig, M., Draisci, R., Giannetti, L., Lucentini, L. (1999). Efficient isolation of the rate diarrhoeic shellfish toxin, dinophysistoxin-2, from marine phytoplankton. Toxicon, 37, 343-357.

Jeffery B., Barlow T., Moizer K., Paul S. and Boyle C. (2004). Amnesic shellfish poison - Review. Food and Chemical Toxicology, 42, 545-557.

Koike K., Sato S., Yamaji M., Nagahama Y., Kotaki Y., Ogata T. and Kodama M. (1998). Occurrence of okadaic acid-producing Prorocentrum lima on the Sanriku coast, northern Japan. Toxicon, 36, 2039-2042.

Lapworth C., Hallegraeff G. M. and Ajani P. A. (2000) Identification of domoic-acidproducing Pseudo-nitzschia species in Australian waters. In: Hallegraeff G. M., Blackburn, S. I., Bolch, C. J., Lewis, R. J. (ed) Harmful Algal Blooms. UNESCO, Tasmania, (pp 38-41).

Lee J. S., Toshihiko Y., Kenma R. and Yasumoto T. (1987). Fluorometric determination of diarrhetic shellfish toxins by high-performance liquid chromatography. Agric Biol Chem, 51, 877-881.

Lefebvre K. A., Powell C. L., Busman M., Doucette G. J., Moeller P. D. R., Silver J. B., Miller P. E., Hughes M. P., Singaram S., Silver M. W. and Tjeerdema R. S. (1999). Detection of domoic acid in northern anchovies and California sea lions associated with an unusual mortality event. Natural Toxins, 7, 85-92.

Lundholm N., Daugbjerg D. and Moestrup O. (2002). Phylogeny of the Bacillariaceae with emphasis on the genus Pseudo-nitzschia (Bacillariophyceae) based on partial LSU rDNA. European Journal of Endocrinology, 37, 115-134.

Mackenzie A. L. and Beuzenberg V. (2003). Production of Gymnodimine by Karenia selliformis. Cawthron, Nelson

Mackenzie L., Beuzenberg V., Holland P., McNabb P. and Selwood A. (2004). Solid phase adsorption toxin tracking (SPATT): a new monitoring tool that simulates the biotoxin contamination of filter feeding bivalves. Toxicon, 44, 901-918.

MacKenzie L., Holland P., McNabb P., Beuzenberg V., Selwood A. and Suzuki T. (2002). Complex toxin profiles in phytoplankton and Greenshell mussels (Perna canaliculus), revealed by LC-MS/MS analysis. Toxicon, 40, 13211330.

Madigan T. L., Lee K. G., Padula D. J., McNabb P. and Pointon A. M. (2006). Diarrhetic shellfish poisoning (DSP) toxins in South Australian shellfish. Harmful Algae, 5, 119-123.

Marr J. C. and Jackson A. E., McLachlan, J. L. (1992). Occurrence of Prorocentrum lima, a DSP toxin-producing species from the Atlantic coast of Canada. J Appl Phycol, 4, 17-24.

Marr J. C., McDowell L. M. and Quilliam M. (1994). Investigation of derivatization reagents for the analysis of diarrhetic shellfish poisoning toxins by lliquid chromatography with fluorescence detection. Natural Toxins, 2, 302-311.

Miles C. O., Wilkins A. L., Munday R., Dines M. H., Hawkes A. D., Briggs L. R., Sandvik M., Jensen D. J., Cooney J. M., Holland P. T., Quilliam M. A., Mackenzie A. L., Beuzenberg V. and Towers N. R. (2004). Isolation of pectenotoxin-2 from Dinophysis acuta and its conversion to pectenotoxin-2 seco acid and preliminary assessment of their acute toxicities. Toxicon, 43, 1-9. 
Miles C. O., Wilkins A. L., Stirling D. J. and MacKenzie A. L. (2003). Gymnodimine $\mathrm{C}$, an isomer of gymnodimine B from Karenia selliformis. Journal of Agriculture and Food Chemistry, 51, 4838-4840.

Miller P. E., Scholin, C. A. (1996). Identification of cultured Pseudo-nitzschia (Bacillariophyceae) using species-specific LSU rRNA-targeted fluorescent probes. Journal of Phycology, 32, 646-655.

Mos L. (2001). Domoic acid: a fascinating marine toxin. Environmental Toxicology and Pharmacology, 9, 79-85.

Mountfort D. O., Suzuki T. and Truman P. (2001). Protein phosphate inhibition assay adapted for determination of total DSP in contaminated mussels. Toxicon, 39, 381-390.

Murakami Y., Oshima Y. and Yasumoto T. (1982). Identification of okadaic acid as a toxic component of a marine dinoflagellate Prorocentrum lima. Bull Jpn Soc Sci Fish, 48, 69-72.

Osborne N. J. T., Webb P. M. and Shaw G. R. (2001). The toxins of Lyngbya majuscula and their human and ecological health effects. Environment International, 27, 381-392.

Pan Y., Cembella A. D. and Quilliam M. A. (1999). Cell cycle and toxin production in the benthic dinoflagellate Prorocentrum lima. Marine Biology, 134, 541-549.

Perl T. M., Bedard L. and Kosatsky T H. J., Todd ECD, Remis RS (1990). An outbreak of toxic encephalopathy caused by eating mussels contaminated with domoic acid. The New England Journal of Medicine, 322, 1775-1780.

Rhodes L. L., Mackenzie A. L. and Kaspar H. F., Todd, K. E. (2001). Harmful algae and mariculture in New Zealand. ICES Journal of Marine Science, 58, 398403.

SASQAP (2004). Biotoxin Report, Pt Lincoln

Scholin C., Miller, P.,Buck, K., Chavez, F., Harris, P., Haydock, P., Howard, J., Cangelosi, G. (1997). Detection and qualification of Pseudo-nitzschia Australis in cultured and natural populations using LSU rRNA-targeted probes. Limnol Oceanogr, 42, 1265-1272.

Seki T., Satake M., Mackenzie L., Kaspar H. F. and Yasumoto T. (1995). Gymnodimine, a New Marine Toxin of Unprecendented Structure Isolated from New Zealand Oysters and the Dinoflagellate, Gymnodinium sp. Tetrahedron Letters, 36, 7093-7096.

Shumway S. E., Allen, S. M., Boersma, P.D. (2003). Marine birds and harmful algal blooms: sporadic victims or under-reported events? Harmful Algae, 2, 1-17.

Skov J., Lundholm N., Moestrup O. and Larsen J. (1999). Leaflet No. 185: Potentially toxic phytoplankton. The diatom genus Pseudo-nitzschia (Diatomophyceae/Bacillariophyceae). International Council for the Exploration of the Sea, 185, Copenhagen

Stirling D. (2001). Survey of historical New Zealand shellfish samples for accumulation of gymnodimine. New Zealand journal of marine and freshwater research abstracts, 35, 851-857.

Ten Hage L., Delaunay N. and Pichon V., Coute, A., Puiseux Dao, S., Turquet, J. (2000). Okadaic acid production from the marine benthic dinoflagellate Prorocentrum arenarium Faust (Dinophyceae) isolated from Europa Island coral reef ecosystem (SW Indian Ocean). Toxicon, 38, 1043-1054.

Toyofuku H. (2006). Joint FAO/WHO/IOC activities to provide scientific advice on marine biotoxins (research report). Marine Pollution Bulletin, In Press, Corrected Proof 
Vale P. (2006). Differential dynamics of dinophysistoxins and pectenotoxins, part II: Offshore bivalve species. Toxicon, 47, 163-173.

Vale P. and Sampayo M. A. d. M. (2003). Seasonality of diarrhetic shellfish poisoning at a coastal lagoon in Portugal: rainfall patterns and folk wisdom. Toxicon, 41, 187-197.

Van Dolah F. M. (2000). Diversity of marine and freshwater algal toxins. In: M B. L. (ed) Seafood and freshwater toxins- pharmacology, physiology and detection. Marcel Dekker Inc., New York (pp 19-43).

Villac M. C. and Fryxell G. A. (1998). Pseudo-nitzschia pungens var. cingulata var. nov. (Bacillariophycese) based on field and culture observations. Phycologia, 37, 269-274.

Wilkins A. L., Rehmann N., Torgersen T., Rundberget T., Keogh M., Petersen D., Hess P., Rise F. and Miles C. O. (2006). Identification of Fatty Acid Esters of Pectenotoxin-2 Seco Acid in Blue Mussels (Mytilus edulis) from Ireland. J. Agric. Food Chem., 54, 5672-5678.

Yasumoto T. and Murata M. (1990). Polyether Toxins involved in seafood poisoning. In: Strichartz H. (ed) Marine Toxins: origin, structure and molecular pharmacology. American Chemical Society (pp 120-132).

Yasumoto T., Seino N., Murakami Y. and Murata M. (1987). Toxins produced by benthic dinoflagellates. Reference: Biol. Bull., 172, 128-131. 
Table 1. Transition Electron Microscope analysis on Pseudo-nitzschia collected from Site 3: Amity Jetty, in February 2005

\begin{tabular}{cccccccc}
\hline Length $\mu \mathrm{m}$ & Width $\mu \mathrm{m}$ & Central Interspace & Rows & Poroids $/ \mu \mathrm{m}$ & Interstriae $/ 1 \mu \mathrm{m}$ & Fibulae/1 $\mu \mathrm{m}$ & Species \\
\hline 63 & 2.3 & Yes & 1 & 5 to 6 & 27 & 12 & P. lineola \\
90 & 1.7 & No & 2 & 3 to 4 & 13 & 15 & P. pungens \\
123 & 4.2 & Yes & 2 & 5 to 6 & 24 & 16 & P. fraudulenta \\
87.5 & 2.3 & Yes & 1 & 4 & 39 & 15 & P. lineola \& cuspidata \\
\hline
\end{tabular}


Table 2. Mean, maximum and sample size of toxins extracted from a) shellfish and b) phytoplankton are divided into those collected from the bay side and the beach side of the island. $\mathrm{OA}=$ okadaic acid; DA domoic acid; GD = gymnodimine; PTX-2 = pectenotoxin-2; PTX-2A = pectenotoxin-2 seco acid.

a) Shellfish

\begin{tabular}{cccccc}
\hline & OA & DA & GD & PTX-2 & PTX-2SA \\
\hline Bay & & & & & \\
Mean $\left(\mu \mathrm{g} \mathrm{kg}^{-1}\right)$ & 0 & 4 & 15 & 2.7 & 0 \\
Max $\left(\mu \mathrm{g} \mathrm{kg}^{-1}\right)$ & 0 & 147 & 137 & 270 & 0 \\
Sample size & 120 & 120 & 120 & 120 & 120 \\
Beach & & & & & \\
Mean $\left(\mu \mathrm{g} \mathrm{kg}^{-1}\right)$ & 2.3 & 10 & 8 & 0.7 & 59 \\
Max $\left(\mu \mathrm{g} \mathrm{kg}^{-1}\right)$ & 44.5 & 256 & 220 & 18 & 1940 \\
Sample size & 72 & 72 & 72 & 72 & 72 \\
\hline Detection limit & 15 & 20 & 0.05 & 1 & 1 \\
\hline
\end{tabular}

b) Phytoplankton

\begin{tabular}{lccccc}
\hline & OA & DA & GD & PTX-2 & PTX-2SA \\
\hline Bay & & & & & \\
Mean $\left(\mu \mathrm{g} \mathrm{L}^{-1}\right)$ & 0 & 0.004 & 0.0003 & 0.0003 & 0.008 \\
Max $\left(\mu \mathrm{g} \mathrm{L}^{-1}\right)$ & 0 & 0.120 & 0.0060 & 0.0350 & 0.170 \\
Sample size & 69 & 69 & 69 & 69 & 69 \\
Beach & & & & & \\
Mean $\left(\mu \mathrm{g} \mathrm{L}^{-1}\right)$ & 0.0003 & 0.003 & 0.00003 & 0.03 & 0.0035 \\
Max $\left(\mu \mathrm{g} \mathrm{L}^{-1}\right)$ & 0.0020 & 0.105 & 0.00040 & 0.26 & 0.0400 \\
Sample size & 70 & 70 & 70 & 70 & 70 \\
\hline
\end{tabular}


Table 3. Calculated mean and maximum dissolved toxin concentration in water (derived from SPATT bags). PTX-2 = pectenotoxin- 2 ; GD = gymnodimine; $\mathrm{OA}=$ okadaic acid.

\begin{tabular}{lccc}
\hline Toxin & PTX-2 & GD & OA \\
\hline Mean $\left(\mu \mathrm{g} \mathrm{L}^{-1}\right)$ & 0.3 & 0.06 & 0.04 \\
Max $\left(\mu \mathrm{g} \mathrm{L}^{-1}\right)$ & 1.1 & 0.3 & 0.2 \\
Sample size & 16 & 16 & 16 \\
\hline
\end{tabular}


Table 4. Estimated daily intake (DI; $\left(\mu \mathrm{g} \mathrm{kg}^{-1} \mathrm{day}^{-1}\right)$ values were calculated using mean and maximum toxin levels in shellfish $\left(\mu \mathrm{g} \mathrm{kg}^{-1}\right)$ from Queensland (QLD) and South Australia (SA), and average shellfish consumption (250 $\left.\mathrm{g} \mathrm{day}^{-1}\right)$ (Toyofuku 2006). 70kg was used as the mean body weight for the calculation of DI. OA = okadaic acid; DA domoic acid; GD = gymnodimine; PTX-2 = pectenotoxin-2; PTX-2A = pectenotoxin-2 seco acid.

\begin{tabular}{lccccc}
\hline & OA & DA & GD & PTX-2 & PTX-2SA \\
\hline Mean toxin in shellfish QLD $\left(\mu \mathrm{g} \mathrm{kg}^{-1}\right)$ & 6.2 & 6.2 & 12.4 & 1.9 & 22 \\
Max toxin in shellfish QLD $\left(\mu \mathrm{g} \mathrm{kg}^{-1}\right)$ & 45 & 256 & 220 & 270 & 1940 \\
Mean toxin in shellfish SA $\left(\mu \mathrm{g} \mathrm{kg}^{-1}\right)$ & 31 & N/A & N/A & 188 & N/A \\
Max toxin in shellfish SA $\left(\mu \mathrm{g} \mathrm{kg}^{-1}\right)$ & 280 & N/A & N/A & 9600 & N/A \\
\hline Mean DI QLD $\left(\mu \mathrm{g} \mathrm{kg}^{-1} \mathrm{day}^{-1}\right)$ & 0.02 & 0.02 & 0.04 & 0.01 & 0.08 \\
Max DI QLD $\left(\mu \mathrm{g} \mathrm{kg}^{-1} \mathrm{day}^{-1}\right)$ & 0.2 & 0.9 & 0.8 & 1 & 7 \\
Mean DI SA $\left(\mu \mathrm{g} \mathrm{kg}^{-1} \mathrm{day}^{-1}\right)$ & 0.1 & N/A & N/A & 0.7 & N/A \\
Max DI SA $\left(\mu \mathrm{g} \mathrm{kg}^{-1} \mathrm{day}^{-1}\right)$ & 1 & N/A & N/A & 34.2 & N/A \\
\hline
\end{tabular}


Sampling sites:

$1=$ Myora Light

2 = Palmer Passage

$3=$ Amity Jetty

$4=$ Flinders Beach

$5=$ Main Beach 1

6 = Main Beach 2

7 = Rous Channell
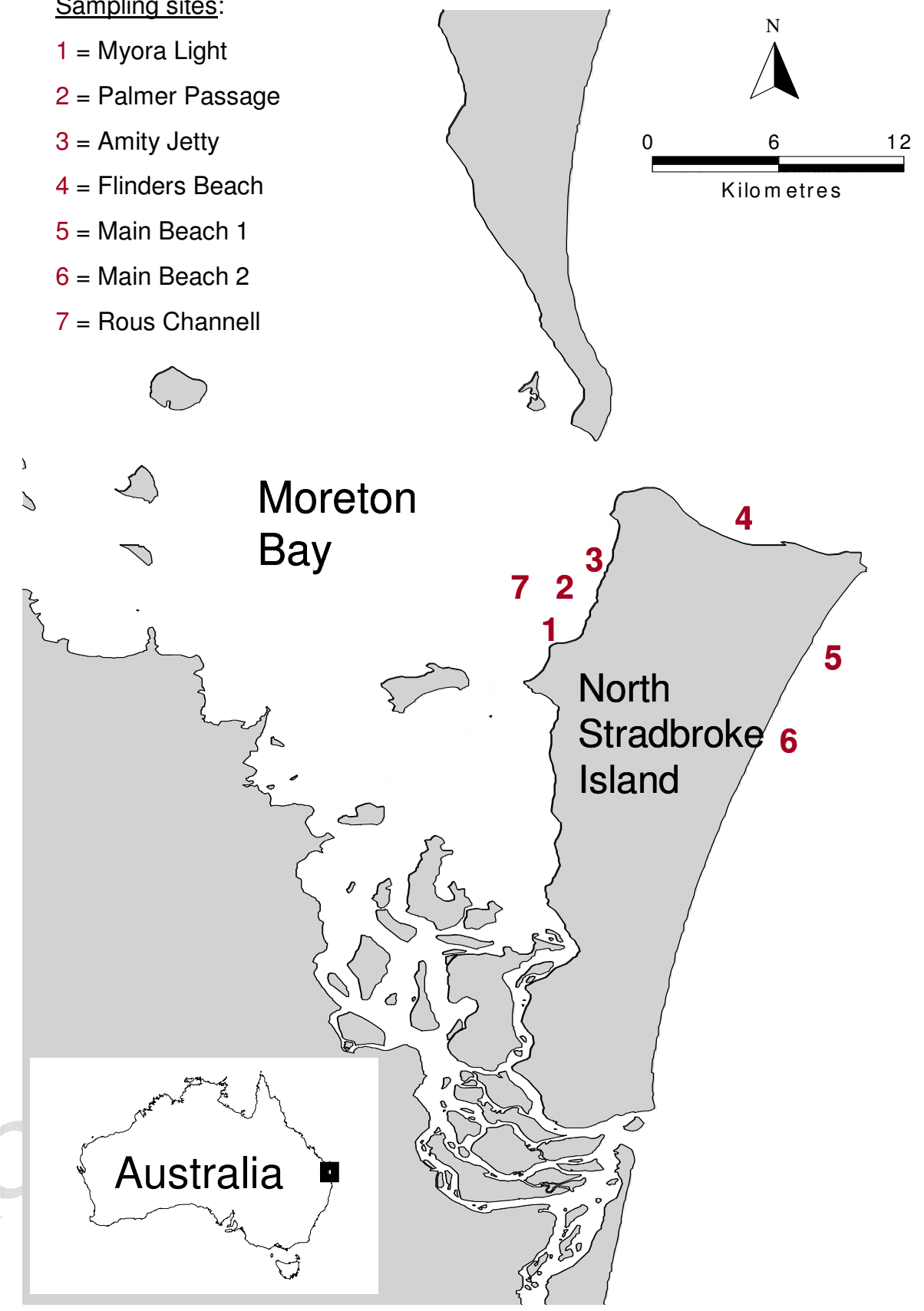

Fig. 1. Map of sampling sites around North Stradbroke Island, off the Southeastern coast of Australia 


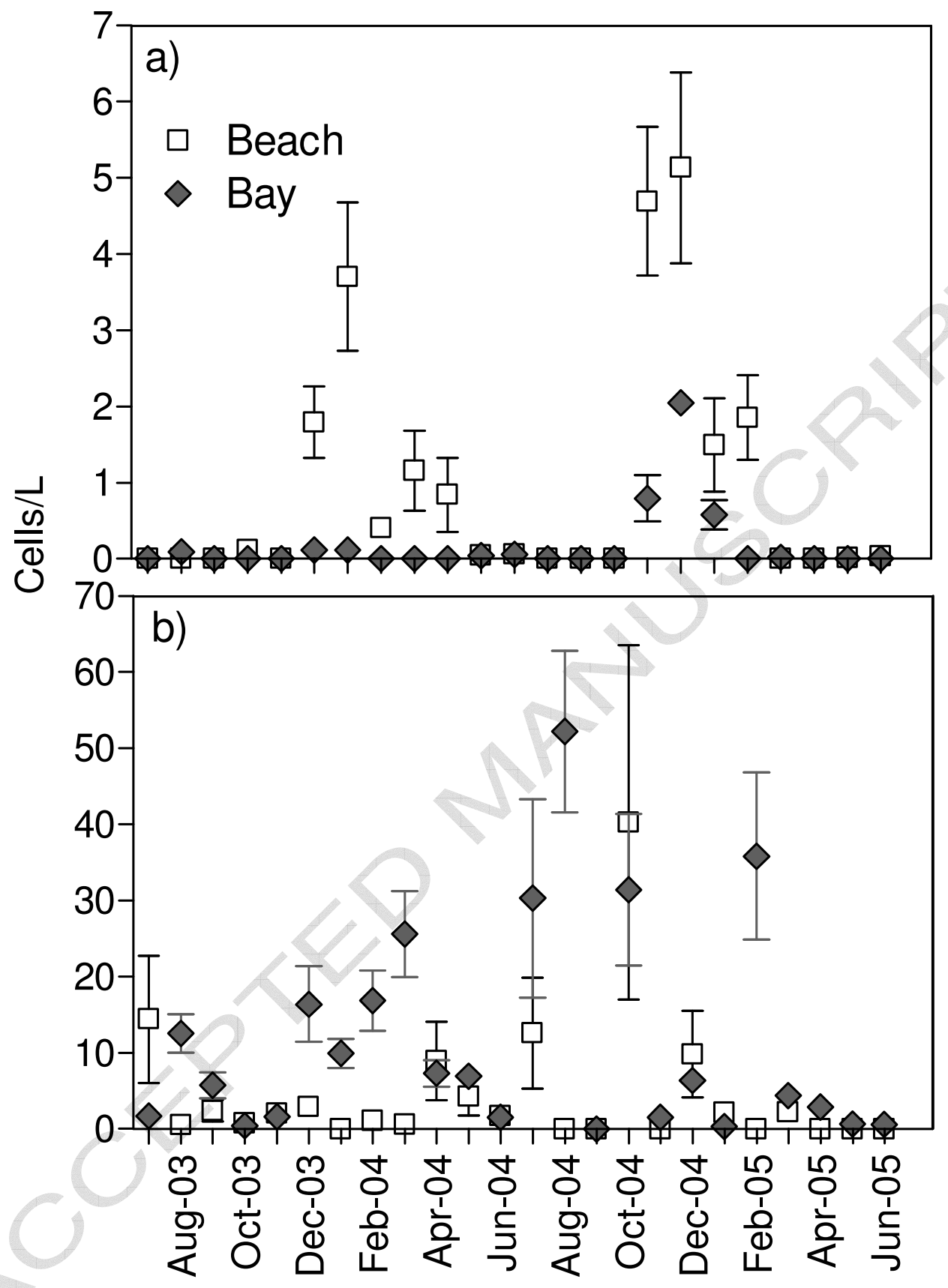

Date

Fig. 2. Number of a) Dinophysis and b) Pseudo-nitzschia cells in the phytoplankton samples collected from the beach and the bay of North Stradbroke Island between July 2003 and June 2005. Bars represent standard errors. 


\section{ACCEPTED MANUSCRIPT}

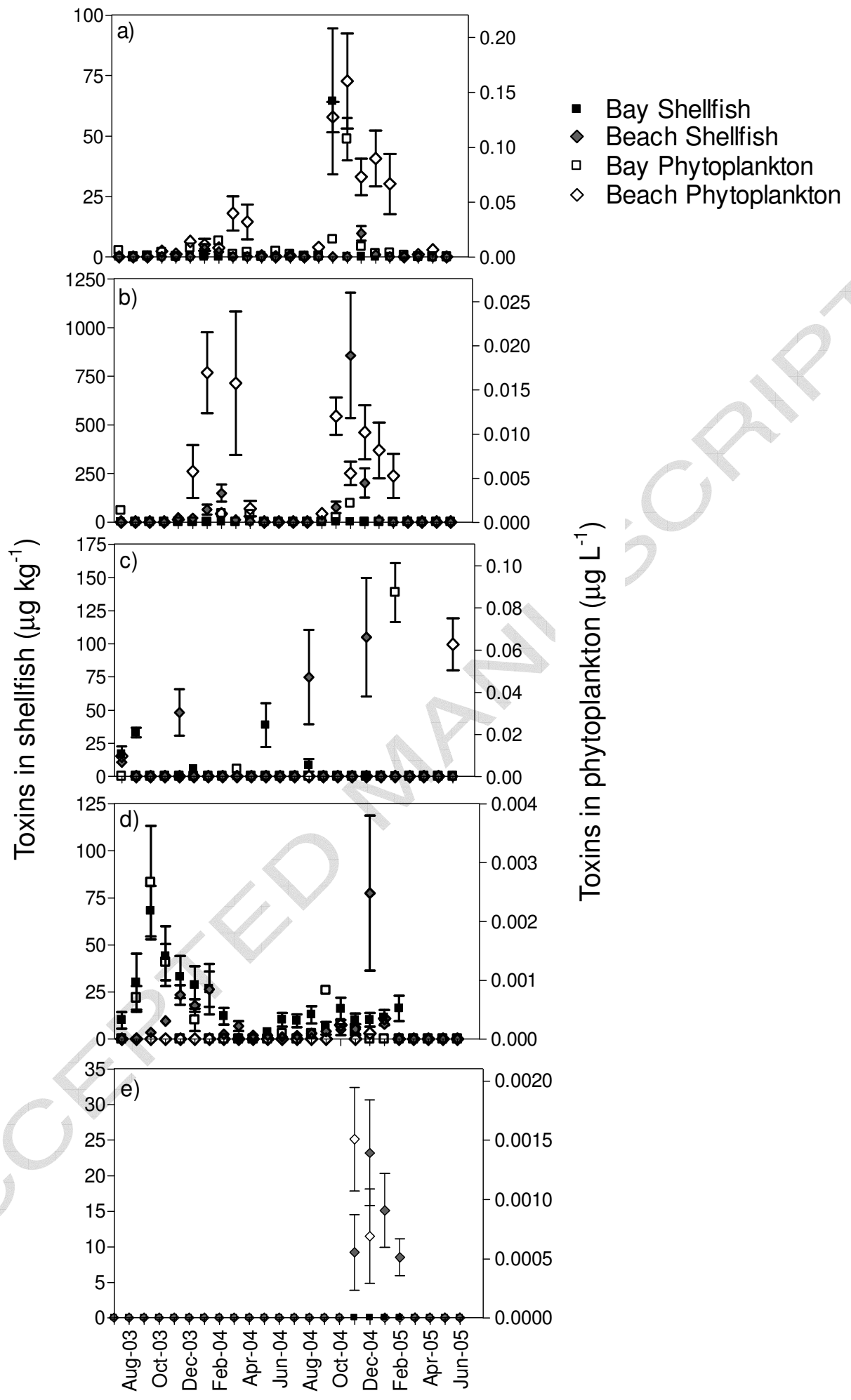

Fig. 3 Average algal toxins extracted from phytoplankton and shellfish samples collected monthly from the bay and the beach of North Stradbroke Island between July 2003 and June 2005. a) Pectenotoxin-2; b) Pectenotoxin -2 seco acid; c) domoic acid; d) gymnodimine; e) okadaic acid. Bars represent standard errors. 


\section{ACCEPTED MANUSCRIPT}

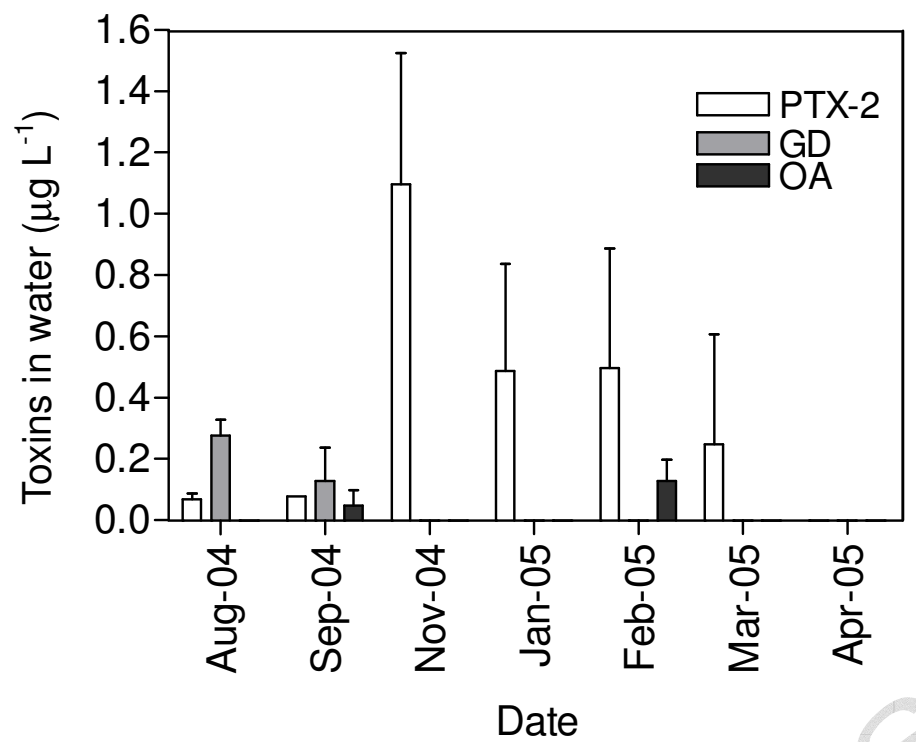

Fig. 4. Estimated dissolved algal toxins in water, extracted from SPATT bags deployed within the bay side of North Stradbroke Island. N/A represents months when samples were not available. Standard errors are shown with error bars. PTX-2 = pectenotoxin-2; GD = gymnodimine $\mathrm{OA}=$ okadaic acid. 